EETP Vol. 14, 2019, №. 4(54)

ISSN 1896-2327 / e-ISSN 2353-7787

DOI: $10.35765 /$ eetp.2019.1454.02

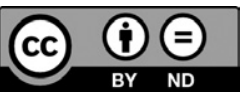

Submitted: 2.10 .2019

Accepted: 19.11.2019

Suggested citation: Jakubowski R., Piotrowski M. (2019). In Search of the Conditions for Permanent Implementation of STEM/STEAM in Polish Schools, "Edukacja Elementarna w Teorii i Praktyce," vol. 14, no. 4(54), pp. 25-37. DOI: 10.35765/eetp.2019.1454.02

\author{
Rafał Jakubowski \\ ORCID: 0000-0002-3587-9583 \\ Teacher Training Center in Kalisz, Poland

\section{Marek Piotrowski} \\ ORCID: 0000-0003-3360-3169 \\ Christian Theological Academy in Warsaw, Poland
}

\title{
In Search of the Conditions for Permanent Implementation of STEM/STEAM in Polish Schools
}

\author{
W poszukiwaniu uwarunkowań trwałego \\ wprowadzenia STEM/STEAM w polskich szkołach
}

\section{KEYWORDS}

STEM, progressive education, $5 \mathrm{E}$ model, 8-point model, mathematical resourcefulness

\section{ABSTRACT}

In this article, the authors focused not only on the STEM/STEAM method, but also on the difficulties which need to be overcome so that this concept can be successfully introduced to the Polish schools. Among the difficulties that need to be overcome, they mention the lack of adaptation of the Polish education to the requirements of the progressive education. The errors of the curricular frameworks force all the students to be taught on the same level.

They warn that, due to the wrongly led early mathematical education, a half of the students with a lower social-family capital have serious difficulties in reaching the mathematical resourcefulness. Therefore, in Poland STEM/STEAM is facing different tasks that anywhere else.

The article is the continuation of the authors' publications connected with creating the heuristic improvements and teaching science by using experiments with the help of scientific methods. Thus, in the next article, which will be the continuation of this publication, they 
will focus on the examples of the issues solved by the children using scientific methods. According to the authors, it is the proposal of overcoming the current difficulties and the possibility to introduce new learning methods, especially STEM/STEAM.

\section{SŁOWA KLUCZOWE ABSTRAKT}

STEM, edukacja progresywistyczna, model 5E, model 8-punktowy
W artykule autorzy skoncentrowali się nie tyle na metodzie STEM/ STEAM, ale na trudnościach jakie należy pokonać, by móc tę koncepcję skutecznie wprowadzić do polskiej szkoły. Wśród przeszkód jakie trzeba przezwyciężyć wymieniają niedostosowanie polskiej szkoły do wymagań edukacji progresywistycznej. Błędy podstawy programowej wymuszającej nauczanie wszystkich uczniów na jednym poziomie.

Autorzy przestrzegają, przypominając, że na skutek złego prowadzenia wczesnoszkolnej edukacji matematycznej połowa uczniów o niższym kapitale rodzinnym - społecznym ma poważne trudności w zdobyciu zaradności matematycznej. Zatem przed STEM/STEAM w Polsce istnieją zasadniczo inne zadania niż gdzie indziej.

Artykuł jest kontynuacją publikacji autorów związanych z kreowaniem uzdolnień heurystycznych oraz nauczania wiedzy poprzez doświadczenia prowadzone za pomocą metody naukowej. Stąd w następnym artykule, kontynuacji niniejszej publikacji, skoncentrują się na przykładach problemów rozwiązywanych przez dzieci za pomocą metod naukowych. Według autorów jest to propozycja przezwyciężania obecnych trudności i możliwość wprowadzenia nowych systemów nauczania, a w szczególności STEM/STEAM.

\section{Introduction}

The following article is another publication related to teaching heuristic abilities through science and mathematics. The authors of the article are two physicists who teach science and mathematics. They are teachers combining their work at school with higher education pedagogy. In the current article, the issues are raised referring to the modern school in Poland, also in terms of the progressive education assumptions. That historical reference to the requirements from 100 years ago should make us realise that the dream about the school that follows the extremely rapid development of social and technological aspects, has been present for years. What we do today by promoting the type of education such as STEM/STEAM is one of the ways of fulfilling very simple requirements formulated in 1919. However, it does not mean that the whole project is easy and obvious. 
It is worth to act sensibly, so that - in a few years' time - our kindergarteners and students can have the impression that they took part in the classes similar to those led by Marie Skłodowska-Curie at the beginning of twentieth century (Chavannes 2004), and not in The Saber-Tooth Curriculum. That satirical commentary was first published in New York in 1939 (Benjamin 1939). The publication has over 65 editions, so it can be assumed that the failures in teaching science have not been a rarity even until now.

That is the reason why the article starts with the remarks about early education of science - education that seems easy, but actually is difficult. Some doubt its point. The article also includes the issue of specific relations between home and school in Poland. The need to change the educational concept has been highlighted, so that the parents do not have to take over the responsibility for the educational success of their child as it currently stands in the early mathematics education. In order for such a change to happen, the teachers should receive the support and not act alone in facing the new challenges related to STEM/STEAM, which has been happening quite often in the current educational reform that has lasted for over 25 years and has not brought the expected results. In conclusion, in relation to the work of the psychologist, Carol Dweck (2013), the postulate was made about the necessity to create the conditions for consistent learning from kindergarten until the secondary school final examination, so that the uniform system would enable the student to systematically develop his/ her heuristic abilities.

According to the authors, the foundation of the school education should be the research activity of a child, demanded in the requirements of progressivists as early as a hundred years ago. The proposed tool that would be worth implementing into the education or, actually, into learning, is the 8-point schedule of classes compatible with the scientific method known to the teachers from their own studies and academic work. It can or even should be reconciled with the STEM/STEAM concept.

The article is the continuation of their work and publications regarding the development of heuristic abilities gathered recently in the publication concerning the early education mathematical resourcefulness (Piotrowski 2018), and the equivalence of the 8-point model to the 5E scheme (Piotrowski, Jakubowski 2019). It also forms the introduction to our next two articles, which present the suggestions for solving the issues discussed in this publication with the help of specific classes conducted according to the STEM/STEAM concept.

\section{Concerns about the point of early science education}

In today's world full of attractions, it is difficult to fascinate a young person with education. We all agree that classes cannot be boring and that they should be a strong 
competition to the available entertainment, but it is becoming harder to compete with the "colourful world" using traditional methods. Based on the research, we can say that there are systems in which the enthusiasm for sciences shrinks in the primary school until the period of early adolescence (Osborne, Simon, Collins 2003; Jenkins, Nelson 2005). At that time, as psychologists claim, the pupils resign from understanding the world using only the support of specific operations. In the defined scope of knowledge, they are able to build their way of perceiving the reality by means of abstract thinking, and they can read and create a symbolic record.

Some teachers, seeing the low genetic correlation, suggest that natural sciences should not be taught during the first years of the school career, and especially in the kindergarten. Instead of natural sciences, teachers suggest that student projects should be conducted during other classes. Taking into consideration the shrinking eagerness observed at the beginning of education, they say that science should be taught at secondary schools as the new and exciting area. They say that children should not be tortured with this subject before their school career even begins. Should we, then, wait until that next stage of the development of cognitive abilities with STEM/STEAM education?

However, this concept raises serious objections among other teachers and parents. They claim that natural sciences in the form of science and mathematics treated seriously (not as counting lessons) should be present in education from preschool to high school. The difficulties in the implementation of those subjects at the beginning of preschool and school education should motivate, and not discourage, us.

It should be remembered that the first editions of the American bestseller written by Janice Van Cleave concerning teaching astronomy, biology, chemistry and physics through hundreds of experiments, were considered worthless at the beginning of the Polish education reform. And they have not been published again, although Van Cleave (2007) was successfully developing her concept of learning including a range of technologies.

Poland is not the only country which has not been reached by good examples of early science education. As a result, in many educational systems we can see the alarming deterioration of creativity as the children grow older. In the research conducted by, inter alia, professor George Land (Markides 2013), it was found that over 98\% of children aged 3-5 were recognised as "creativity geniuses." After 5 years, the number of "creativity geniuses" decreased to just 32\%, and after 10 years - to $12 \%$. In the group of adults (aged over 25), only $2 \%$ of the respondents met the criteria of a "creativity genius." 


\section{Eight conditions of STEM/STEAM education}

Therefore, the conditions of the implementation of STEM/STEAM in Poland can be formulated as follows:

1. The necessity to introduce the review of school and students in the form of certificates, and not the competitions and school contests, as Microsoft has done for years (2011).

2. The necessity to support teachers with the proper materials necessary for their work, and connecting these materials with the government's curriculum, as it was done in Ireland (Bruton 2017).

3. The necessity to introduce classes based on the rules of problem-based learning, and not treating them as the addition - supplement to thematic learning (LaForce, Noble, Blackwell 2017).

4. The necessity for the classes to be implemented during normal lessons, so that their effects are not mainly associated with homework and support of parents or private teachers as it is nowadays e.g. with mathematics (Piotrowski 2018).

5. The necessity to implement classes based on the principle of searching for solutions and verifying various hypotheses (European Commission 2015).

6. The necessity to introduce evaluation similar to formative assessment, but in a very simplified format (Jakubowska, Pokroper 2008).

7. The necessity to consider two or three levels of achievements, so that every child can experience successes and failures (Dweck 2008).

8. The necessity for detailed planning, so that a student can feel the effect of Eureka, not just the wow-effect.

The first requirement. We must ensure that the early education period is not lost to the development of cognitive abilities and heuristic skills for the majority of the students, and not just for a small, several-percent group. Therefore, let us forget about the system of working with the talented student (singular number) and contests. We should strive for the general certificates such as "I have finished the program of 8 experiments with magnets," which could cover the biggest group of students from the preschoolers to high-school graduates. Microsoft has supported education using the certificates for a long time (2011).

The second requirement. Looking for organisational solutions, we must remember that the condition for teachers' success is providing them with specific guidance in teaching in kindergartens and early education. The requirements should explicitly conform to the curriculum, ensuring understanding the aims and planning schedules for the classes. In the history of the Polish reform there were many interesting and noteworthy ideas, but they have not been transformed into specific ideas, so they were ultimately abandoned; for example, the cross-curricular paths which 
appeared in the curriculum in 1999 (Suchańska 2001) and disappeared 9 years later. What we need are solutions similar to the ones implemented in Ireland (Bruton 2017), at least - at the beginning - in a residual form.

The third requirement. The goal of STEM/STEAM should be the change of thematic learning (e.g. learning how to multiply) into the problem-based learning consisting of formulating research questions (e.g. how can we facilitate learning the multiplication table and what does its diagram look like?) and encouraging the students to act (LaForce, Noble, Blackwell 2017).

Teaching should develop the skills to formulate and solve problems. Such operations require time and accepting the fact that students making errors learn the most. Therefore, STEM/STEAM must be connected with a different system of grading than the current one and with a dialogue with the student and parents.

\section{The relation of home vs. kindergarten and school}

We cannot afford to transfer science education to the home environment, just like we practically did in Poland with mathematical education, as a result of which only the children of parents, of whom at least one has higher education, have mathematical skills when finishing early education (Piotrowski 2016).

Other students, accounting for more than 50\%, are able to solve a mathematical problem when it is similar to the one learnt and "rooted" at school. Parents are able to support Polish school in teaching mathematics and in it - their children, only when they are people of a high SES - socio-economic status (Milerski, Karwowski 2016: 121-144).

The glass ceiling manifesting itself in strong dependence of the level of students' achievements on their family capital is present not only in Poland, and it is not a new phenomenon. That barrier not only restricts the educational development, but also the economic and technological development, as well as beneficial social changes. Presumably, the first attempt to find a solution to this problem on a wider scale was made at the beginning of the twentieth century in the USA by the founders of the Progressive Education Association established in 1919 (Wraga 2014). In their programme documentation, we can find the following recommendation: " 4 . The teacher, the school and the parents should cooperate together, aiming for the progress in the child's development" (Gutek 2003):

It is the fourth out of six requirements addressed to the teachers and parents and the school for an average, American family - not to the private enclave with high tuition fees attended by the children from rich families. The communities of industrialists founding the Progressive Education Association believed that the development of 
the USA would be threatened if an average citizen was not able to meet the requirements connected with the rapidly reformed and developing economy after the First World War.

In Poland, in terms of mathematics, the successful cooperation between teachers, parents and the school has never been achieved. People were not convinced of the necessity to teach all students in such a way so that they could gain mathematical resourcefulness and continue to build their knowledge according to the constructivist principles.

The fourth requirement. STEM/STEAM materials should be prepared for regular classes. They cannot be something additional, extraordinary, implemented during after-school activities or, by no means, based only on homework. Obviously, the children can repeat at home (e.g. in the kitchen) what they learnt at school, according to the principle that a good school is the one in which the students happily continue - at home - the learning process started during the classes. Otherwise, the children's abilities may disappear as in the mathematical Bermuda Triangle (Piotrowski 2018).

\section{The child's research activity}

In the requirements for the public schools raised by the Progressive Education Association (100 years ago) there was also a specific requirement about the research activity of a child - the third one out of six requirements: " 3 . The teacher should give direction to the research activity of a child" (Gutek 2003: 298). Similar recommendations were defined by the European Parliament in 2006 and repeated in 2018: "Mathematical competence and competence in science, technology and engineering (...). Competences in natural sciences concern the abilities and willingness to explain the world of nature using the existing knowledge and applied methods, including the observations and experiments, in order to form questions and draw conclusions based on the evidence" (Council recommendation 2018).

Despite the incorrect research, including PISA 2012, our students do not have these competences (Kasprzak 2014).

The fifth requirement. It is related to the fact that problem-based learning should not only be based on research questions, but also on various hypotheses concerning them, and searching for the most likely one. It is the essence of scientific research. This requirement might seem to be quite perverse for some teachers and authorities. Especially if they believe that school should be the place of giving only true information and opinions, and if they remember that in the core curriculum for junior high schools the term "hypothesis" was considered unnecessary. Changing that 
paradigm, which is valid not only in the Polish schools, is expected by the European Union (2015).

$\mathrm{Grading}$. After removing the effect of guessing, only a half of the students can solve more than $30 \%$ tasks appearing in the secondary school exam in science and mathematics (Piotrowski, Jakubowski 2019). It means that almost a half of the secondary school students would not pass that exam if they had to give at least $30 \%$ of the correct replies or if the questions were open ended (not closed/multiple choice questions).

It is difficult to expect that modern science and mathematics teachers will understand or at least accept that degradation of education in the STEM/STEAM system, because - in their school and academic work - they are evaluated by the exams with the minimum passing limit of 50\%. All the more since the modern English exams, on level A2 and B1, have even a higher passing level (Davies 2019).

In this situation, the current grading system must be changed. We should go back to the basics defined by, among others, Black (2006). At the same time, we have to remember that wrong - i.e. too broad, formative assessment leads to illusionary acts (Jakubowska, Pokropek 2008).

The sixth requirement. The necessity to match the grading method with the requirements of STEM/STEAM. The method should be similar to the formative assessment, but its form should be much more simplified than the ones offered to the teachers during popular courses. The method of grading should take into account the increase (not the level) of new competences, starting from the early stages of education.

\section{Favourable approach to learning - the attitude towards self-development}

Carol Dweck, a psychologist, describes two kinds of attitudes towards self-development in her books, lectures and articles - a fixed attitude and developmental attitude. Based on the research conducted with her co-workers, she presented how the approach focused on development - a developmental attitude leads to better results (success) and, which is also very important, how such approach can be achieved (Blackwell, Trześniewski, Dweck 2008).

Dweck states that people who have a fixed attitude believe that intelligence and talent are natural and cannot be changed. This leads to the belief that talented people do not have to take up any new challenges, and if they do and fail, they will lose their reputation. 
In Poland, a fixed attitude is constantly present in the positive assessments of students, such as "intelligent but lazy." It is believed that the students shall succeed anyway because they are intelligent. This way, their attitude is accepted. However, as time goes on, it often turns out that tolerating laziness leads to educational and personal failure. But, with the school having such a low prestige as in the Polish society, it is difficult to realise that the term "intelligent but lazy" is a warning - a negative, and not a positive, grade that confirms the student's skills.

Dweck and her team proved many times that adults and children having a fixed attitude avoid challenges, because, with time, they lose the belief that they can learn something that does not come naturally to them. Coming out of their comfort zone makes them risk the lack of success which they treat as a failure, and they cannot bear it. Many students have a fixed attitude. Some of them gained this approach during the earliest stages of education - as a result of their environment at home, the influence of their parents and siblings, and - later - the approach of the teachers at school. In the Polish school, a fixed approach is generated by teaching all pupils on the same level, even in terms of science and mathematics, from kindergarten until they are 15-16 years old. Differentiation of the levels of education could result in the situation in which each student can experience both - successes and failures, in a natural manner - the same as while learning how to walk, run, jump, swim... While teaching students on the same level, we divide them into those who continuously achieve successes and those who get used to failures. Because successes are related to the high SES, the Polish educational system very often discriminates pupils from their first day at school (Murawska 2007).

Dweck reminds us that every parent and teacher knows, from their own experience, the series of children's questions beginning with "Why?" However, she also states that in a kindergarten group, around $90 \%$ of questions are asked by several most active children. Other kindergarteners are passive. Quite often, these attitudes are the result of the children's previous experiences.

The children whose questions were patiently answered and who were encouraged to conduct independent researches, are determined to long-term learning. They gain the resistance to failure, because they notice that failure is a source of discovering new cause and effect relationships. Looking for mistakes in reasoning, they gain the ability of critical thinking.

The seventh requirement. STEM/STEAM activities should be conducted on two - three levels of achievement, so that every child could experience successes and failures. 


\section{Systematic implementation of the concept}

Many pedagogical researches and theoretical deliberations support the postulate promoted by, among others, Dweck: a passion for something, involvement and selfdevelopment, and not inborn intelligence, are the effective ways to achieve success (Turska 2012).

Dweck emphasises that persistent determination is a passion and tenacity in achieving long-term aims. It is durability and patient holding on to the plan for the future - not just for a week or month, but for years. It is hard work to fulfil the plan. Persistence means treating life like a marathon, not a sprint.

However, both promoters and receivers of that postulate often refer it to the unit the student. Not to the system or to the creation of the conditions in which the student can develop his/her passions and, through involvement, undergo the process of self-development. The student's persistence and self-discipline do not have to lead to success. We can imagine a student who consistently memorises knowledge that is given to them. Is it enough for them to achieve success in professional work? In the previous era of slow economic and social development, such restriction of activity could be enough. But today...?

In Poland, in the early mathematical education, the qualitative change of conditions specified by the system is the requirement introduced to the curriculum, so that the student can not only solve the tasks, but also create them (Ministerstwo Edukacji Narodowej 2017). Unfortunately, this change was implemented without additional comments based on the research, which suggest that the ability to create tasks is not as strongly connected with SES as other abilities shaped during maths lessons (Jakubowska 2018). Creating tasks leads to learning through dialogue and increasing the effectiveness of teaching starting from early education (Alexander 2018). Therefore, it can be the foundation of systematic, long-term learning of other subjects, not just maths.

If we want to create the skills required in the $21^{\text {st }}$ century specified by STEM/ STEAM, not only the student needs to be persistent in learning, but also the school must consequently, in a deliberate way, create the situations in which the student will be obliged to learn the surrounding reality through actions. Therefore, the problems must appear in many areas of school practice, which can be solved using methods introduced by STEM/STEAM. It is not an easy demand. We already have some successes in teaching science and technology. The teachers, not only in Poland, are getting used to the empirical methods of teaching mathematics (Lockhart 2012). The school's empirical research in other subjects is already reflected in practice (Piotrowska 2017). However, we are lacking consistent curricula. 
The eighth requirement. We should design the classes in such a way that the student can not only be surprised with the achieved result (the WOW effect), but also, due to recalling the previous classes, he/she can feel the effect of Eureka. In such a situation, the teacher can offer the student the logical continuation of the majority of the students' discoveries.

\section{Summary}

The concepts similar to STEM/STEAM, consisting in changing the way and meaning of school education, were postulated by J. Piaget 70 years ago in the publication entitled Where is education going? and by J. Bruner, who introduced the term discovery learning. Although many years have passed since those two works were published and their concept was called educational constructivism, we are not really sure how we should effectively introduce the method of developing STEM/STEAM skills in schools. There are many solutions found in a very large collection of educational models, but although they seem very valuable, they are not reflected in what is happening at school. After experiencing many failures, 8 requirements were presented above, which could increase the likelihood of a successful implementation of the STEM/STEAM concept into kindergartens and schools.

Until now, one of partially successful attempts are the students' scientific research activities. Therefore, the next publications will be focused on the examples of the application of the 8-point research scheme, both to science and mathematics, and to its use in the STEM/STEAM model. The suggested examples should also explain the way of meeting the requirements presented in this publication.

\section{Bibliography}

Alexander R. (2018). Developing Dialogic Teaching: Genesis, Process, Trial, "Research Papers in Education," vol. 33(5), pp. 561-598. DOI: 10.1080/02671522.2018.1481140.

Benjamin H. (1998). Edukacja jaskiniowców, trans. M. Lawergne, Warszawa: Wydawnictwo Uniwersyteckie "Żak".

Black P., Harrison Ch., Lee C., Marshall B., Wiliam D. (2006). Jak oceniać, aby uczyć?, trans. J. Dutkiewicz, Warszawa: Wydawnictwo "Civitas".

Blackwell L., Trześniewski K., Dweck C. (2008). Implicit Theories of Intelligence Predict Achievement Across an Adolescent Transition: A Longitudinal Study and an Intervention, "Child Development," vol. 78(1), pp. 246-263. DOI: 10.1111/j.1467-8624.2007.00995.x.

Bruton R. (2017). STEM Education Policy Statement 2017-2026. Dublin: Department of Education and Skills. 
Chavannes I. (2004). Lekcje Marii Sktodowskiej-Curie. Notatki Isabelle Chavannes z 1907 roku, trans. M. Jarosiewicz, Warszawa: Wydawnictwa Szkolne i Pedagogiczne.

Council recommendation of 22 May 2018 on key competences for lifelong learning (Text with EEA relevance) (2018/C 189/01), https://eur-lex.europa.eu/legal-content/EN/TXT/ PDF/?uri=CELEX:32018H0604(01)\&from=EN (access: 12.10.2019).

Davies K. (2019). Exam updates 2020, Cambridge: Cambridge University Press, https:// keyandpreliminary.cambridgeenglish.org/.

Dweck C. (2013). Nowa psychologia sukcesu, trans. A. Czajkowska, Warszawa: Wydawnictwo Muza S.A.

Gutek G. (2003). Filozoficzne i ideologiczne podstawy edukacji, trans. A. Kacmajor, A. Sulak, Gdańsk: Gdańskie Wydawnictwo Psychologiczne.

Jakubowska M. (2018). Diagnoza rozumowania heurystycznego w procesie rozwiazywania i tworzenia zadań z treścia, "Studia z Teorii Wychowania," vol. 9, no. 4(25), pp. 279300, https://files.clickweb.home.pl/af/9c/af9c01e4-5c66-4301-88af-ab70e9c1b91f. pdf (access: 12.10.2019).

Jakubowska M., Pokropek A. (2008). Ewaluacja oceniania ksztattującego, Warszawa: Polsko-Amerykańska Fundacja Wolności.

Jenkins E., Nelson N. (2005). Important but not for me: Students' attitudes owards Secondary school science in England, "Research in Science and Technological Education," vol. 23(1), pp. 41-57. DOI: 10.1080/02635140500068435.

Kasprzak P. (2014). Cud nad Wista 2012. Raport Fundacji OFF o polskich wynikach w badaniach PISA dla Paktu dla Szkoty, Warszawa: Fundacja OFF.

Komisja Europejska. (2015). Science Education for Responsible Citizenship, Brussels: Directorate-General for Research and Innovation. DOI: 10.2777/12626.

LaForce M., Noble E., Blackwell C. (2017). Problem-Based Learning (PBL) and Student Interest in STEM Careers: The Roles of Motivation and Ability Beliefs, "Education Sciences MDPI,” vol. 7(4), pp. 1-22. DOI: 10.3390/educsci7040092.

Lockhart P. (2012). Measurement. Cambridge, MA: Harvard University Press.

Markides C. (2013). Do schools kill creativity? "Business Strategy Review," vol. 24(4), pp. 6-7. DOI: 10.1111/j.1467-8616.2013.00983.x.

Microsoft. (2011). STEM: A Foundation for the Future, Improving Student Skills in Science, Technology, Engineering, and Math, Redmond, WA: Microsoft Corporation, https:// www.slideshare.net/simchabe/microsoft-and-stem-science-technology-engineeringmath (access: 12.10.2019).

Milerski B., Karwowski M. (2016). Racjonalność procesu ksztatcenia. Teoria i badanie. Kraków: Oficyna Wydawnicza "Impuls".

Ministerstwo Edukacji Narodowej, Rozporządzenie Ministra Edukacji Narodowej z dnia 14 lutego 2017. (2017). Podstawa programowa kształcenia ogólnego dla szkoły podstawowej. Dz.U. 2017, no. 356, p. 37.

Murawska B. (2007). Segregacje na progu szkoty podstawowej, Warszawa: Instytut Spraw Publicznych. 
Osborne J., Simon S., Collins S. (2003). Attitudes Towards Science: A Review of the Literature and its Implications, "International Journal of Science Education," vol. 25(9), pp. 1049-1079. DOI: 10.1080/0950069032000032199.

Piotrowska K. (2016). English Language Abstracts for Online Pedagogical Discourse During CLIL at Special Subject Lessons in Polish Schools. Warszawa: WPSW.

Piotrowski M. (2016). Btędne podstawy edukacji matematycznej i sposoby ich naprawienia. Zandarma trzeba odwotać, chociaż jest $w$ nas samych, "Studia z Teorii Wychowania," no. 3(16), pp. 95-122, http://cejsh.icm.edu.pl/cejsh/element/bwmeta1.element.desklight-e28367d9-f74f-4683-9943-cbb8fd9895f7/c/SzTW_2016_3_95_Marek_Piotrowski.pdf (access: 12.10.2019).

Piotrowski M. (2018). Matematyczny Trójkąt Bermudzki - trudności w ksztatceniu zaradności matematycznej, "Studia z Teorii Wychowania," no. 3(24), pp. 289-310. DOI: 10.24131/3724.190103.

Piotrowski M., Jakubowski R. (2019). The New Face of Science Education in Poland, "Edukacja," no. 1(148), pp. 40-48. DOI: 10.24131/3724.190103.

Suchańska M. (2001). Ścieżki edukacyjne - teoria i praktyka. Materiaty do wewnątrzszkolnego doskonalenia nauczycieli, Kielce: Oficyna Wydawnicza Nauczycieli.

Turska D. (2012). Teorie inteligencji Carol Dweck i ich edukacyjne implikacje, "Psychologia Wychowawcza," no. 1-2, pp. 44-54.

VanCleave J. (2007). Engineering for Every Kid: Easy Activities That Make Learning Science Fun, Hoboken: John Wiley \& Sons Inc.

Wraga W. (2014). Condescension and Critical Sympathy: Historians of Education on Progressive Education in the United States and England, "Paedagogica Historica," vol. 50(1-2), pp. 59-75.

\section{ADDRESS FOR CORRESPONDENCE}

Rafał Jakubowski

Teacher Training Center in Kalisz, Poland e-mail: rafal.jakubowski@odn.kalisz.pl

Marek Piotrowski

Christian Theological Academy in Warsaw, Poland e-mail: marek.a.piotrowski@gmail.com 